\title{
A Semmelweis Egyetem extracorporalis membránoxigenizációs programja - az 5 éves Városmajori-eredmények függvényében
}

\author{
Hartyánszky István dr. ${ }^{1 *}$ - Koppányi Ádám dr. ${ }^{1 \text { * }}$ \\ Szabolcs Zoltán dr. ${ }^{1}$ - Horkay Ferenc dr. ${ }^{1}$ - Fazekas Levente dr. ${ }^{1}$ \\ Hüttl Tivadar dr. ${ }^{1}$ - Pólos Miklós dr. ${ }^{1}$ - Daróczi László dr. ${ }^{1}$

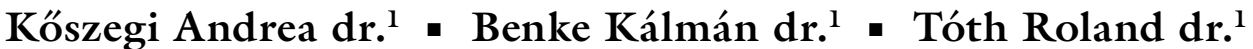 \\ Kovács Péter dr. ${ }^{1}$ - Barabás János Imre dr. ${ }^{1}$ - Németh Endre dr. ${ }^{2}$ \\ Édes István Ferenc dr. ${ }^{1}$ - Merkely Béla dr. ${ }^{1}$ \\ Semmelweis Egyetem, Általános Orvostudományi Kar, 'Városmajori Szív- és Érgyógyászati Klinika, \\ ${ }^{2}$ Aneszteziológiai és Intenzív Terápiás Klinika, Budapest
}

\begin{abstract}
A mechanikus keringéstámogatás az elmúlt 5 évben programmá fejlődött a Városmajori Szív-és Érgyógyászati Klinikán. Mindehhez szükséges volt a megfelelő Szívtranszplantációs és Szívelégtelenségi Intenzív Osztály kialakítása, valamint a megfelelő eszköz- és humánerőforrás-fejlesztés. Jelenleg már a teljes mechanikus keringéstámogatási arzenállal rendelkezünk, aminek köszönhetően minden indikációban és minden stratégiában ellátást tudunk biztosítani mind rövid, mind közép-, mind pedig hosszú távon a végleges múszívbeültetéssel bezárólag. Munkánkban megvizsgáltuk az elmúlt 5 évben végzett extracorporalis membránoxigenátor (ECMO-) beültetéssel szerzett eredményeinket. Klinikánkon 2012 és 2017 között összesen 140 betegnél alkalmaztunk mechanikus keringéstámogatást, valamennyi esetben konvencionális terápiával nem stabilizálható szívelégtelenség esetén. ECMO-terápiát 111 alkalommal végeztünk: szívátültetést követően 33 alkalommal, 18 alkalommal szívmútét utáni postcardiotomiás szindróma miatt, 37 esetben akut myocardialis infarctus utáni akut keringési elégtelenség miatt, 14 alkalommal végstádiumú szívelégtelen betegek akut keringésmegingása miatt, 4 esetben súlyos légzési elégtelenség, 1 esetben gyógyszermérgezés miatti malignus ritmuszavar, 3 esetben szövődményes katéteres aortamübillentyü-implantáció állt a háttérben. A 2018. első félévi adataink a korábbi adatok és indikációk tendenciáját tükrözik, az esetszám jelentős emelkedésével. Eredményeink szerint a terápia összesített mortalitása 46\% volt. A mechanikus keringéstámogatás eredményeinek vizsgálatakor elengedhetetlen a paradigmaváltás. A mortalitási adatokat nézve betegeink felét elveszítettük, ugyanakkor ebben a betegcsoportban a betegek $100 \%$-a meghalt volna a konvencionális terápia mellett, vagyis az ECMOterápia sikerességének megítélésekor nem a mortalitási, hanem a túlélési adatokat kell tekinteni.
\end{abstract}

Orv Hetil. 2018; 159(46): 1876-1881.

Kulcsszavak: mechanikus keringéstámogatás, ECMO, múszív

The Semmelweis University extracorporeal membrane oxygenation program 5 years' results and perspectives

The mechanical circulatory support (MCS) program of the Semmelweis University Heart and Vascular Centre has become established over the last five years. The main requirements of our MCS program to be developed first were the Heart Transplantation and Heart Failure Intensive Care Unit and a well trained medical team. The wide range of mechanical circulatory support devices provides suitable background for the adequate treatment of our patients in all indications. In this review, we present our results related to extracorporeal membrane oxygenation (ECMO) supports performed in the last five years. Between 2012 and 2017, we applied MCS support in 140 cases, among them 111 
patients received ECMO support. The leading indications of ECMO support were the following: primary graft failure after heart transplantation (33 cases), postcardiotomy cardiogenic shock (18 patients), acute decompensation of end-stage heart failure (14 patients), acute myocardial infarction complicated with refractory cardiogenic shock (37 patients), cardiogenic shock developed after transcatheter aortic valve implantation (3 patients), malignant arrhythmia due to drug intoxication ( 1 patient) and acute respiratory distress syndrome ( 4 cases). The mortality of patients receiving ECMO support was $46 \%$. The analysis of the results of ECMO support needs to change our approach. The mortality results show that we lost the half of our patients. However, the mortality in the conventionally treated patients would have been $100 \%$ without ECMO. In fact, we could save the life of half of these patients.

Keywords: mechanical circulatory support, ECMO, artificial heart

Hartyánszky I, Koppányi Á, Szabolcs Z, Horkay F, Fazekas L, Hüttl T, Pólos M, Daróczi L, Kőszegi A, Benke K, Tóth R, Kovács P, Barabás JI, Németh E, Édes IF, Merkely B. [The Semmelweis University extracorporeal membrane oxygenation program - 5 years' results and perspectives]. Orv Hetil. 2018; 159(46): 1876-1881.

(Beérkezett: 2018. szeptember 9.; elfogadva: 2018. szeptember 28.)

\begin{abstract}
Rövidítések
AMI $=$ (acute myocardial infarction $)$ akut myocardialis infarctus; ARDS = (acute respiratory distress syndrome) akut légúti distressz szindróma; $\mathrm{CHF}=($ chronic heart failure $)$ krónikus szívelégtelenség; $\mathrm{ECMO}=$ (extracorporeal membrane oxygenator) extracorporalis membránoxigenátor; HTX = (heart transplantation) szívtranszplantáció; IABP = intraaorticus ballonpumpa; MCS = (mechanical circulatory support $)$ mechanikus keringéstámogatás; TAVI = (transcatheter aortic valve implantation) katéteres aortamúbillentyú-implantáció; VA = venoarteriosus; VSD = (ventricular septal defect $)$ keringés-öszszeomlás; $\mathrm{VV}=$ venovenosus
\end{abstract}

A mechanikus keringéstámogatás indikációja akkor merül fel, amikor akut vagy krónikus szívelégtelenségben a szív pumpafunkciója annyira lecsökken, hogy nem tudja az életfontosságú szervek múköodéséhez szükséges perfúziót biztosítani. Az extracorporalis membránoxigenátor (ECMO) a mechanikus keringéstámogató eszközök egyik fajtája, mely mind a megfelelő perctérfogatot, mind pedig a vér oxigenizációját képes biztosítani. Az elmúlt években felbecsülhetetlen szerepet kezdett játszani mind a súlyos szív-, mind pedig a kritikus tüdőbetegségek kezelésében, melyeknél a konvencionális intenzív terápiával az alapvető életfunkciók már nem biztosíthatók. Az ECMO-terápiát szupportív terápiaként kell felfogni, vagyis nem a betegséget kiváltó okot szünteti meg, hanem a létfontosságú szervek (szív és/vagy tüdő) feladatát átvéve időt ad annak gyógyulására. Alkalmazásának sikerét alapvetően meghatározza, hogy helyes indikációval és megfelelő konfigurációban, a megfeleló páciensnél alkalmazzuk, a kiváltó ok reverzibilitásának időintervallumán belül [1].

Története az 1940-es évekig nyúlik vissza, amikor Kolff és Berk megfigyelték, hogy az általuk létrehozott, celofánt tartalmazó művesén keresztüláramló vér oxigenizálódott. Elsőként 1953-ban Gibbon alkalmazott mesterséges keringést és oxigenátort nyitott szívmútét során. Hosszú távú ECMO-kezelést az 1970-es években alkalmaztak sikeresen először egy beteg trauma kiváltotta ARDS-kezelése során. Igazi áttörést a 2000-es évek közepén a CESAR-tanulmány hozott, mely légzési elégtelenség következtében ECMO-terápiában részesülő betegek túlélését vizsgálta konvencionális terápiában részesülókkel szemben, és eredménye alapján mind a túlélésben, mind a hospitalizáció idejében, mind ezek következményeképp a kezelési költségekben hatékony módszernek bizonyult.

A mechanikus keringéstámogatás azon eszközök öszszességét jelenti, melyek a testbe beültetve a szív pumpafunkcióját helyettesítik, szükség szerint a vér oxigenizációját is biztosítják. Felosztásuk több elven lehetséges; időbeliségük alapján megkülönböztetünk rövid távú (1-7 nap), középtávú (1 héttôl 3 hónapig) és hosszú távú (3 hónap-évek) keringéstámogató eszközöket. További csoportosítási elv az áramlási profil alapján történhet, mely szerint vannak folyamatos áramlást biztosító eszközök, és vannak pulzatilis áramlást leadó eszközök. A folyamatos áramlást leadó eszközök múködési elve a bennük lévő magnetikus tér és a térben elektromágneses elven mozgatott propeller. A folyamatos 'flow'-t leadó pumpák előnye, hogy bennük a mechanikai súrlódás elhanyagolható, mert a mágneses térben lebeg a propeller. Ennek következtében az ezen elven alapuló készülékek hosszú távon is alkalmazhatók, szemben a pulzatilis áramlást biztosító eszközökkel, melyek mechanikus pumpálással továbbítják a vért, így élettartamuk korlátozottabb [2].

A mechanikus keringéstámogató eszközök összetétele a szívmútétek során alkalmazott szívmotor múködési elvén alapul, vagyis szükségünk van kanülökre, melyekkel a beteg testéből elvezetjük, illetve visszavezetjük a vért, egy csőrendszerre, mellyel a véráramlást biztosítjuk a beteg és a pumpa között, és szükségünk van egy motorra, mely mozgási energiát ad a véroszlopnak. Mindemellett oxigenátorral is kiegészíthetô a rendszer, melynek segítségével a gázcsere végbemehet a beteg testén kívül. 
A fent említett eszközök segítségével képesek vagyunk a jelentôsen károsodott vagy adott esetben hiányzó szív vagy tüdő funkciójának pótlására. Szív esetében lehetőségünk van izoláltan a jobb vagy a bal kamra, adott esetben pedig mindkét szívfél pótlására. Ha a tüdő funkciója károsodik, a szív viszont képes megfelelő keringést fenntartani, akkor csak a vénás rendszerbe beültetett támogató eszközt alkalmazunk. Ezt venovenosus ECMO-nak (VV ECMO) nevezzük. A leggyakoribb kanülálásnál a vena femoralisból vezetjük el a vért az ECMO-készülékbe, ahol a megfelelő oxigenizáció után a vért visszavezetjük egy vena jugularis kanülön keresztül a jobb pitvarba. Amikor a szív funkcióját is pótolnunk kell, a VV ECMOhoz hasonló rendszert építünk fel, azzal a különbséggel, hogy az oxigenizált vér nem a jobb szívfélbe, hanem az artériás rendszeren keresztül a szisztémás keringésbe jut: ezt a rendszert venoarteriosus, röviden VA ECMO-nak nevezzük. A kanülök pozíciója alapján megkülönböztetünk perifériás és centrális ECMO-t. Perifériás ECMO esetén a törzsön kívüli kanülpozícióról beszélünk (femoralis, illetve axillaris régiók), míg centrális ECMO esetén a kanülök a szív körüli nagyerekben (aorta), illetve üregekben (jobb pitvar) helyezkednek el. Centrális ECMO használata a leginkább szívsebészeti beavatkozások során gyakori, amikor a szív-tüdő motor funkcióját a mútétet meghaladó ideig szükséges alkalmazni. Perifériás VA ECMO-t elsősorban sürgősségi helyzetekben, olyan keringés-összeomlás esetén használunk, mint például a kardiogén sokk. A két kanülálási technika között alapvető különbség, hogy a centrális ECMO anterográd 'flow'-t tud biztosítani, hemodinamikailag alkalmasabb a balkamra-detenzionálásra, így előnyösebb a szív regenerációja szempontjából. Beültetése azonban több időt igényel, és komplikáltabb, hiszen mellkast kell hozzá nyitni, emiatt az infekciós és vérzéses szövődmények kockázata is magasabb. A perifériás ECMO gyorsan elindítható, ezért alkalmas akut keringés-összeomlásban, újraélesztésben, ugyanakkor megemeli a szív utóterhelését, ebből következik, hogy a szív pihentetésére nem alkalmas, illetve alsó végtagi ischaemiát is okozhat. A mechanikus keringéstámogatási rendszerek közül az ECMO a rövid idejű eszközök közé tartozik; a VA ECMO-terápia alkalmazásának biztonságos ideje 7-10 nap, a VV ECMO hosszabb ideig, pár hétig alkalmazható [3]. A VA és a VV ECMO tulajdonságainak összehasonlítása az 1. táblázatban látható.

A VA ECMO-terápia indikációi között a legfontosabb a kardiogén sokk vagy súlyos szívelégtelenség, mely hátterében állhat szívinfarktus, ritmuszavarok vagy krónikus szívelégtelenség akut exacerbatiója. További alkalmazása szívmütétek során a szív-tüdő motor funkciójának hoszszabb távú pótlása, szívtranszplantáció során a primer graftelégtelenség kezelése [4].

A VV ECMO elsődleges indikációi közé tartozik a különböző eredetű súlyos légzési elégtelenség, mely klinikailag lehet ARDS vagy végstádiumú tüdőbetegség.
1. táblázat |A VA és a VV ECMO tulajdonságainak összehasonlítása

\begin{tabular}{ll}
\hline VA ECMO & VV ECMO \\
\hline $\begin{array}{l}\text { Keringéstámogatás a szisztémás } \\
\text { keringés fenntartásának } \\
\text { érdekében }\end{array}$ & Nincs keringéstámogató funkció \\
\hline $\begin{array}{l}\text { Artériás és vénás kanülálás } \\
\text { szükséges }\end{array}$ & Csak vénás kanülálás szükséges \\
\hline $\begin{array}{l}\text { Kikerüli a tüdókeringést: } \\
\text { csökkenti a kis vérköri artériás } \\
\text { nyomást }\end{array}$ & \\
\hline $\begin{array}{l}\text { Jobbkamra-elégtelenségben is } \\
\text { használható }\end{array}$ & $\begin{array}{l}\text { Nem használható jobbkamra- } \\
\text { elégtelenségben }\end{array}$ \\
\hline Magasabb PaO $\mathrm{Pa}_{2}$ érhetó el & \\
\hline
\end{tabular}

ECMO = extracorporalis membránoxigenátor; $\mathrm{PaO}_{2}=$ parciális oxigénnyomás; VA = venoarteriosus; $\mathrm{VV}=$ venovenosus

Nem szabad ugyanakkor megfeledkezni arról a tényről sem, hogy igen invazív beavatkozásról van szó, mely erőteljesen megváltoztatja a beteg homeosztázisát. Éppen ezért nem elhanyagolható az ECMO-terápia szövődményrátája sem. A leggyakoribb szövődmény a vérzés, mely az irodalmi adatok szerint 10-30\%-ban fordulhat elő. A vérzéses szövődmények hátterében a leggyakrabban a kanülálás során létrejövő érsérülés állhat. A vérzéses szövődmény lehetőségét növeli a heparin alkalmazása, hiszen a műanyag csőszett és az oxigenátor felszíne miatt az ECMO-kezelés alatt folyamatos antikoagulálás szükséges. Ez olyan kényes egyensúly fenntartását igényli, amelytől eltérve azonnal vagy vérzéses, vagy thromboemboliás szövődményt kaphatunk, mely szövődmények a leggyakoribbak az ECMO-kezelés során. A pumpa okozta szövődmények közül a leggyakoribb a thrombocytadiszfunkció és az alvadási faktorok dilúciója következtében kialakuló coagulopathia vagy a heparin indukálta thrombocytopenia. Emellett előfordulhat ECMO használata során tüdővérzés, intracerebralis vérzés vagy cerebralis hipoperfúzió is [5]. Fóképp centrális ECMO alkalmazása során kell számolnunk az infekciós szövődményekkel. Periférás VA ECMO alkalmazása során létrejöhet úgynevezett Harlequin-szindróma, melynek alapja, hogy az alsó és a felső testfél között oxigenizációs különbség alakul ki. Ez akkor jöhet létre, ha a szív pumpafunkciója kezd visszatérni, viszont a tüdő oxigenizációs funkciója még nem javul. Az anterográd és retrográd 'flow' egymással versenyez; ha ez helyileg az aortaívból eredő nagyerektől proximalisan alakul ki, akkor a felső végtagokba és az agyba a tüdőből érkező alacsonyabb oxigénszaturációjú vér juthat. Perifériás ECMO alkalmazásakor az 'afterload' emelkedése miatt az egyik legsúlyosabb szövődmény a bal kamra disztenziója. Így a bal szívfélben megemelkedő nyomás miatt kialakulhat a súlyos akut tüdőödéma, mely akár pár óra alatt olyan irreverzibilis károsodásokat okozhat, melyek a beteg halálához vezethetnek. 
Célunk volt áttekinteni a Klinikán végzett ECMO-beültetéseink adatait, eredményeinket összehasonlítani a nemzetközi eredményekkel, valamint megvizsgálni az ECMO-programban történő változtatásokat és összehasonlítani a 2012-2017-es és 2018-as adatainkat.

\section{Módszerek}

Klinikánkon az ECMO-támogatásra Deltastream (Medos Medizintechnik AG, Heilbronn, Németország) és CentriMag (Abbott Laboratories, Chicago, IL, Amerikai Egyesült Államok) készülékeket használtunk, szükség esetén oxigenátor- (Medos) beültetéssel. Mindkét rendszer hasonló moduláris felépítésű: a csőszettből ki- és beépíthető az oxigenátor, mindkettő alkalmazható kis és nagy vérkörben, és mindkettő centrifugális pumpafejjel rendelkezik. A 2012 és 2017 közötti időszakban összesen 111 betegünk adatát, míg 2018 első felében 28 beteg adatát dolgoztuk fel. Vizsgáltuk az ECMO-terápia indikációját, a terápia időintervallumát, valamint a betegek túlélését. Adataink feldolgozásához a Klinikánkon létrehozott CorDb-adatbázis rendszerét használtuk, eredményeinket Kaplan-Meier-analízissel vizsgáltuk.

\section{Eredmények}

A Városmajori Szív- és Érgyógyászati Klinika mechanikus keringéstámogató programja 2012-ben jött létre, melynek keretén belül 2017 végéig összesen 140 beteget kezeltünk. Ezzek közül a legnagyobb gyakorisággal ECMO-terápiát alkalmaztunk, összesen 111 alkalommal (60 perifériás és 51 centrális kanülálás). A terápia alkalmazása 33 alkalommal szívátültetést követően, 18 alkalommal szívmütétet követően, 37 esetben akut myocardialis infarctust követő akut hemodinamikai instabilitást követően, 14 alkalommal krónikus szívelégtelen betegek akut keringés-összeomlása kapcsán, 4 esetben súlyos légzési elégtelenség következtében, l esetben gyógyszer-intoxikáció következtében kialakult malignus ritmuszavar miatt, 3 alkalommal szövődményes TAVI után került sor. Az alkalmazott terápia során a 10 napos mortalitás megközelítette az 50\%-ot, a 10 nap utáni terápia során a mortalitás drasztikusan emelkedett. A leghosszabb ideig tartó kezelésünk 15 nap volt (1. ábra).

ECMO-implantációt 2018-ban július közepéig összesen 28 alkalommal végeztünk, ebből 13 centrális és 15 perifériás kanülálással történt, 3 alkalommal szívtranszplantációt követően, szintén 3 alkalommal szívmütétet követően, AMI kapcsán 11, AMI-t követő VSD kialakulása miatt 2 alkalommal, krónikus szívelégtelenség akut dekompenzációja miatt 4 , légzési elégtelenség miatt 3 , myocarditis kapcsán pedig 2 alkalommal. Az ECMO-terápia 14 napos mortalitása klinikai adatbázisunk (Cordb) szerint egyre javuló eredményt mutat, hiszen 2012-ben még csak 33\%-os túlélésról beszélhettünk, míg 2018ban ez az arány már 63\%. A 30 napos túlélést tekintve is hasonló fejlődés mutatkozik eredményeinkben, 2012-

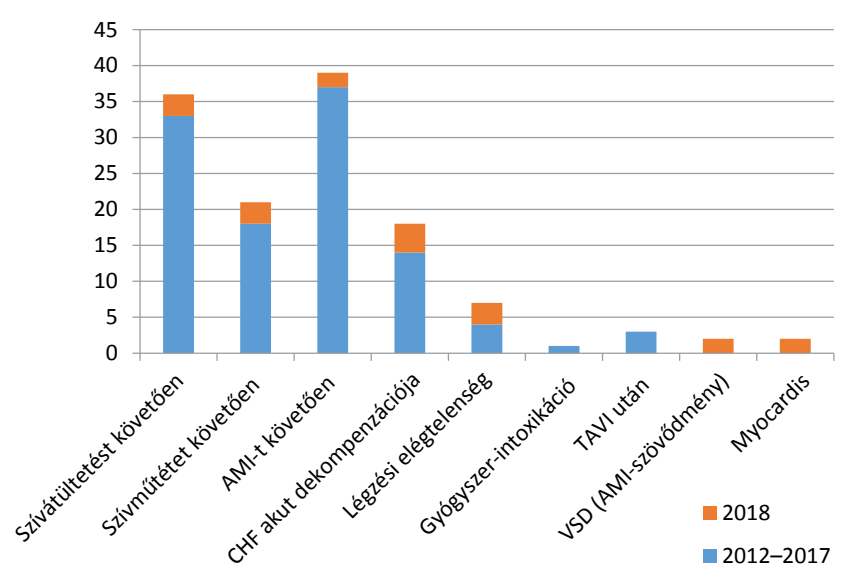

1. ábra

ECMO-terápia 2012 és 2018 között a Városmajori Szív- és Érgyógyászati Klinikán

AMI = akut myocardialis infarctus; $\mathrm{CHF}=$ krónikus szívelégte lenség; $\mathrm{ECMO}=$ extracorporalis membránoxigenátor; TAVI = katéteres aortamúbillentyú-implantáció; VSD = keringés-összeomlás

ben ez 33\%, míg 2018-ban 53\%. A hosszú távú túlélés (2012-tôl napjainkig) hasonló fejlődést mutat, a terápia bevezetésekor 11\%, 2018-ban már 38\%. ECMO-terápiában részesülő betegeink átlagéletkora $47 \pm 6,2$ év, a nemek aránya pedig megközelítőleg 30\%-ban nőbeteg, $70 \%$-ban férfi beteg.

\section{Megbeszélés}

Az egyes mechanikus keringéstámogató stratégiák egymásra épülnek, stratégiai piramist alkotnak, melynek alját elérhetőség és indikációs gyakoriság alapján az ECMOkezelés képzi. A Klinikánkon alkalmazott mechanikus keringéstámogatás a nemzetközi tendenciákat követi mind stratégiában, mind pedig az alkalmazott eszközök előfordulásában. Adataink jól tükrözik, hogy a leggyakrabban választott és alkalmazott mechanikus keringéstámogatási modalitás az ECMO-kezelés volt, aminek oka, hogy akut esetben, vagy ha nem áll megfelelő mennyiségû információ birtokunkban a beteg állapotáról, akkor ez az elsőként választandó és a legkönnyebben elérhető keringéstámogató eszköz. A mechanikus keringéstámogatás eredményeinek vizsgálatakor elengedhetetlen a paradigmaváltás, hiszen ha szimplán a mortalitási adatokat nézzük, betegeink felét elveszítettük. Ebből a szemszögből nézve jogosan merülhet fel a kérdés, hogy van-e létjogosultsága egy ekkora mortalitású terápiának. Ha azonban jobban belegondolunk, ebben a betegcsoportban a betegek döntő többsége meghalt volna a konvencionális terápia mellett, vagyis betegeink felét meg tudtuk menteni. Tehát nem a terápia során veszítettük el betegeink felét, hanem éppen ellenkezóleg, a terápia segítségével betegeink közel felét meg tudtuk menteni. Nemzetközi adatok alapján az ECMO-kezelés átlagos túlélése 50\%-os, melynek alapján az általunk elért eredmények a nemzetközi eredményekkel korrelálnak [6]. 
Eredményeink alapján jól látszik, hogy a 10 napnál hosszabb ECMO-kezelés esetén drasztikusan csökken a túlélés (2. ábra). Ennek hátterében több tényező állhat: valószínúleg a 10 napnál hosszabb terápiára szoruló betegek alapvetően rosszabb állapotú betegek több társbetegséggel, eleve kisebb túlélési eséllyel, amit egyébként nemzetközi adatok is alátámasztanak. Az ECMO-kezelés szövődményei (infekció, neurológiai károsodási arány, thromboemboliás kockázat) 7 nap után jelentkeznek nagyobb számban, ami a mortalitás növekedésével függ össze. Ez alapvetően meg kell, hogy határozza stratégiánkat is, vagyis az ECMO-támogatás során már a kezelés felénél (3-4 napnál) gondolkoznunk kell, hogy hogyan tudjuk a kezelést a hetedik napnál abbahagyni. Ez azt jelenti, hogy ez alatt az egy hét alatt el kell döntenünk, hogy a beteget esetlegesen milyen további mechanikus keringéstámogató eszközre helyezzük, vagy ha van reményünk az ECMO-kezelés abbahagyására a hetedik napon, akkor az ehhez szükséges összes támogató terápiát időben elkezdjük, hogy a 7-10 napos maximális kezelési időintervallumot ne haladjuk meg. Adataink alapján jól látszik, hogy az egyre könnyebb elérhetőségnek köszönhetően az ECMO-kezelés száma nagymértékben növekszik, hiszen míg 2017-ben összesen 30 beteget kezeltünk, addig 2018 első félévében már 28 beteg részesült ECMO-támogatásban.

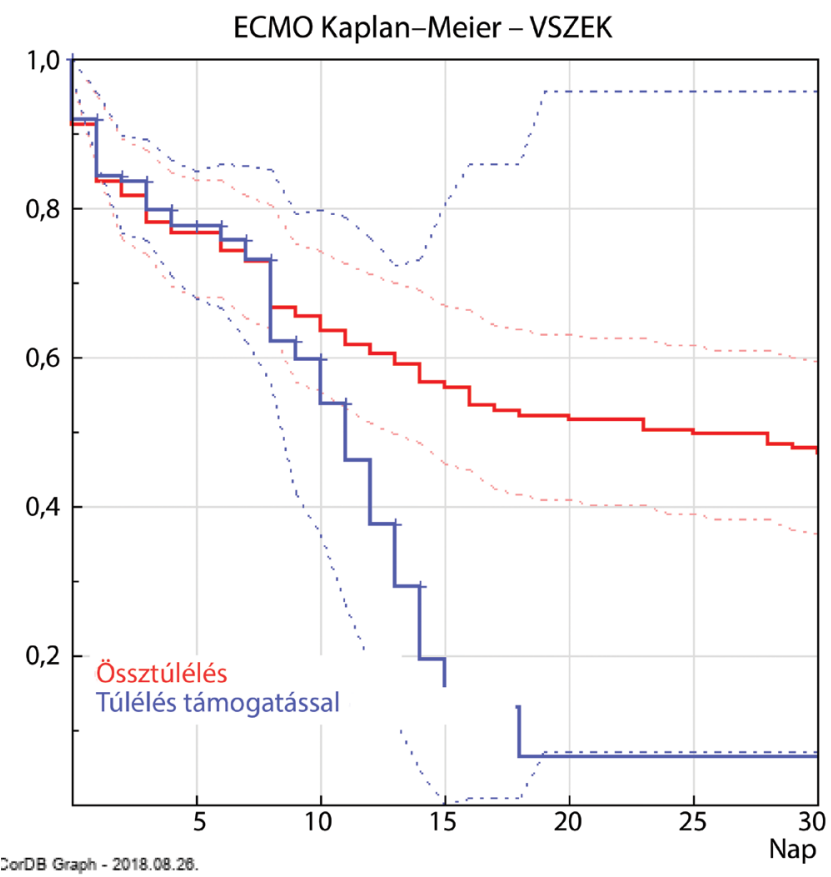

2. ábra

Az ECMO-terápiában részesült betegek 30 napos túlélése

Össztúlélés: Az ECMO-beültetésre került betegek összesített túlélése a támogatás kezdetétől

Túlélés támogatással: Azon ECMO-támogatásban részesült betegek túlélése, akiket nem lehetett az ECMO-készülékrôl levenni

Jól látszik, hogy az ECMO-támogatás 7-10. napján a még támogatáson lévő betegek túlélése jelentősen esik

$\mathrm{ECMO}=$ extracorporalis membránoxigenátor; VSZEK $=$ Város majori Szív- és Érgyógyászati Klinika
Eredményeink alapján az is látszik, hogy a szívmütétek során alkalmazott ECMO-terápia mortalitása alacsonyabb, mint az AMI során indított ECMO-kezelésé. Ennek hátterében az állhat, hogy a szívmútét utáni ECMOkészülék-behelyezés tervezetten történhet, illetve időveszteség nélkül tudjuk implantálni az eszközt és elindítani a kezelést. A bevezetésben részletezett hemodinamikai elvek alapján az is látszik, hogy a centrális ECMO kedvezőbb hatással bír a myocardium számára, hiszen a szív terhelésének csökkentésével a szívizom regenerációja gyorsabban bekövetkezhet, illetve az utóterhelés csökkentésével a tüdőödéma kialakulásának kisebb a valószínúsége.

Az ECMO-kezelés alkalmazása során egyre jobb eredményeket tapasztalunk, a mortalitás csökkenő tendenciát mutat. Ennek hátterében több dolog állhat. Egyrészt a terápia egyre gyorsabban elérhető, szükség esetén akár 12 perc alatt megtörténhet a kanülálás, és elindulhat az ECMO-készülék. Másrészt a terápia bizonyos szövődményei is kisebb mértékben mutatkoznak, ennek oka lehet, hogy a perifériás kanülálás során kisebb átmérőjü kanült használunk, mert nem szükséges a teljes perctérfogatot biztosítani. Ezáltal az érkárosodások száma is csökkent. Emellett a vérzéses szövődmények számát is sikerült csökkentenünk, mivel a terápiás antikoagulálást a behelyezést követően 24 órával indítjuk el.

Akut keringés-összeomlás esetén az irreverzibilis metabolikus károsodások elkerülése érdekében az ECMOtámogatás mielőbbi indítása szükséges. A gyors hozzáférhetőség miatt ebben az indikációban a perifériás VA ECMO javasolt. Ahhoz, hogy a hozzáférést javítsuk, úgynevezett 'fast-deployment' stratégiát vezettünk be. Ennek lényege, hogy egy ECMO-készülék folyamatosan összeszerelt és feltöltött állapotban van, így akár a mütőben, akár a hemodinamikai laboratóriumban vagy az intenzív osztályon van rá szükség, azonnal felhasználható, és az érkezéstől számított 30 percen belül az ECMOkezelés elindítható. Az ECMO-támogatás túlélésbeli fejlődésében több tényező játszik fontos szerepet. Az egyik legfontosabb tényező, hogy a terápia időbeli elérhetősége egyre fejlődik. A beteg megérkezésétől számítva akár 12 percen belül elindulhat a kezelés; ehhez szükség van az eszközös háttér folyamatos elérhetőségére, a személyzet megfelelő képzettségére, a kezelés fenntartásához szükséges intenzív osztályra és ami a legfontosabb, a megfelelő indikációra.

A fentiek alapján felmerül annak szükségessége, hogy az ECMO-kezelés országos szintű programmá fejlődjön. Alkalmazása elsősorban szívsebészeti háttérrel rendelkező szívcentrumokban jöhetne először szóba, hiszen itt találkozunk első körben az akut myocardialis infarctus korai mechanikus szövődményeivel (VSD), valamint szívmútét után akár 2-6\%-os prevalenciával kialakuló postcardiotomiás szindrómával. További széles körű alkalmazási lehetőség lehetne az akut myocardialis infarctust követő akut balszívfél-elégtelenség kezelése. A legújabb ajánlások szerint a kardiogén sokkos betegek 
ellátásában az intraaorticus ballonpumpa (IABP) egyre inkább háttérbe szorul, sőt egyes adatok szerint már nem is ajánlott $[7,8]$. Ezzel szemben a hemodinamikai laborban minden adott a perifériás nagyerek kanülálásához, a perifériás ECMO-támogatás elindításához, melynek segítségével stabilizálható a beteg állapota, a tervezett beavatkozás elvégezhető [9-11]. Adott helyzetben időt nyerhetünk a további terápiás döntésig, vagy megteremtődhet a lehetőség a beteg másik centrumba történő szállítására. Mindezek alapján szükséges lenne a szívcentrumok megfelelő eszközös fejlesztése, valamint az emberi erőforrás megfelelő oktatása az ECMO-kezelés alkalmazására [12-14].

\section{Következtetés}

Mára Klinikánkon a mechanikus keringéstámogatást programmá alakítottuk, teljes eszközparkkal rendelkezünk, így minden indikációval és minden stratégiában alkalmazni tudjuk. Az általunk akut keringés-összeomlás vagy szívmútét utáni elégtelen pumpafunkció kapcsán kezelt közel 100\%-os mortalitású betegpopulációnál sikerült jelentős túlélésbeli eredményt elérnünk, a mortalitást közel 50\%-ra csökkentettük. A hazai és a nemzetközi eredmények ismeretében szükségesnek látjuk, hogy az ECMO-terápia országos programmá fejlődjön, melynek a központjait a szívsebészeti háttérrel rendelkező szívcentrumok alkothatnák, hiszen itt találkozunk a leggyakrabban az akut myocardialis infarctus szövődményeivel (VSD, keringés-összeomlás), és rendelkezünk azzal a teljes terápiás repertoárral, melynek segítségével a lehető legeffektívebben tudnánk az ECMO-terápiát alkalmazni.

Anyagi támogatás: A közlemény megírása anyagi támogatásban nem részesült.

Szerzői munkamegosztás: H. T., P. M., D. L., K. A., B. K., T. R.: Koncepció és irodalomkutatás. K. P., B. J. I., N. E., É. I. F.: Analízis és interpretáció. M. B., Sz. Z., H. I., K. Á., H. F., F. L.: Kéziratszerkesztés. A cikk végleges változatát valamennyi szerző elolvasta és jóváhagyta.

Érdekeltségek: A szerzőknek nincsenek érdekeltségeik.

\section{Irodalom}

[1] Fazekas L, Sax B, Hartyánszky I, et al. Mechanical circulatory support saves lives - three years' experience of the newly established assist device program at Semmelweis University. Budapest, Hungary. [A mechanikus keringéstámogatás életet ment - a múszívprogram első három évének tapasztalata a Semmelweis Egyetemen.] Orv Hetil. 2015; 156: 521-527. [Hungarian]

[2] Baran DA. Extracorporeal membrane oxygenation (ECMO) and the critical cardiac patient. Curr Transplant Rep. 2017; 4: 218225.

[3] Hartyánszky I, Sax B, Fazekas L, et al. State of the art of the mechanical circulatory device therapy in Hungary - the Városmajor experience. [A mechanikus keringéstámogatás helyzete Magyarországon a Városmajor eredményeinek tükrében.] Cardiol Hung. 2017; 47: 112-118. [Hungarian]

[4] Tsao NW, Shih CM, Yeh JS, et al. Extracorporeal membrane oxygenation-assisted primary percutaneous coronary intervention may improve survival of patients with acute myocardial infarction complicated by profound cardiogenic shock. J Crit Care 2017; 27: 530.el-530.ell.

[5] Cheng R, Hachamovitch R, Kittleson M, et al. Complications of extracorporeal membrane oxygenation for treatment of cardiogenic shock and cardiac arrest: a meta-analysis of 1,866 adult patients. Ann Thorac Surg. 2014; 97: 610-616.

[6] Makdisi G, Wang IW. Extra Corporeal Membrane Oxygenation (ECMO) review of a lifesaving technology. J Thorac Dis. 2015; 7: E166-E176.

[7] Descaillot L, Harbaoui B, Emsellem P., et al. Use of intra-aortic balloon pump in cardiogenic shock: evidence-based or experience-based? Insights from a historical, real life comparison. Arch Cardiovasc Dis Suppl. 2018; 10: 149.

[8] Nemeth E, Szigeti S, Varga T, et al. Continuous cytokine haemoadsorption incorporated into a venoarterial ECMO circuit for the management of postcardiotomy cardiogenic and septic shock - a case report. Perfusion 2018; 33: 593-596.

[9] Szudi L, Székely L, Sápi E, et al. Perioperative use of levosimendan in cardiac surgery. Hungarian recommendation. [A levoszimendán perioperatív alkalmazása a szívsebészetben. Magyar ajánlás.] Orv Hetil. 2018; 159: 870-877. [Hungarian]

[10] Lakatos B, Kovács A, Tokodi M, et al. Assessment of the right ventricular anatomy and function by advanced echocardiography: pathological and physiological insights. [A jobb kamrai anatómia és funkció korszerú echokardiográfiás vizsgálata: patológiás és fiziológiás eltérések.] Orv Hetil. 2016; 157: 11391146. [Hungarian]

[11] Szentmihályi I, Barabás JI, Bali Á, et al. Heart transplantation and long-term lvad support cost-effectiveness model. [Szívtranszplantáció és múszívkezelés költséghatékonysági elemzési modellje.] Magy Seb. 2016; 69: 186-193. [Hungarian]

[12] Mazzeffi MA, Tanaka K, Roberts A, et al. Bleeding, thrombosis, and transfusion with two heparin anticoagulation protocols in venoarterial ECMO patients. J Cardiothorac Vasc Anesth. 2018 Aug 3. pii: S1053-0770(18)30597-4. [Epub ahead of print]

[13] Bartos JA, Carlson K, Carlson C, et al. Surviving refractory outof-hospital ventricular fibrillation cardiac arrest: critical care and extracorporeal membrane oxygenation management. Resuscitation 2018 ; 132: 47-55.

[14] Zakhary B, Nanjayya VB, Sheldrake J, et al. Predictors of mortality after extracorporeal cardiopulmonary resuscitation. Crit Care Resusc. 2018; 20: 223-230.

(Hartyánszky István dr., Budapest, Városmajor u 68., 1122 e-mail: drharist@gmail.com)

A cikk a Creative Commons Attribution-NonCommercial 4.0 International License (https://creativecommons.org/licenses/by-nc/4.0) feltételei szerint publikált Open Access közlemény, melynek szellemében a cikk nem kereskedelmi célból bármilyen médiumban szabadon felhasználható, megosztható és újraközölhető, feltéve, hogy az eredeti szerző és a közlés helye, illetve a CC License linkje és az esetlegesen végrehajtott módosítások feltüntetésre kerülnek. 